\title{
Protective Effect of Acmella Ciliata Extract and Spilanthol in Streptozotocin-induced Sporadic Alzheimer's Disease Mouse Model: Possible Involvement of the of Decreased Oxidative Stress by Activating TRPV1 Receptors
}

\section{Ana Elisa Goncalves}

UNIVALI: Universidade do Vale do Itajai

\section{Narjara Silveira}

UFSC: Universidade Federal de Santa Catarina

Luana de Oliveira

UNIVALI: Universidade do Vale do Itajai

Marihá Gonzaga Lima

UNIVALI: Universidade do Vale do Itajai

Maique Biavatti ( $\square$ maique.biavatti@ufsc.br)

UFSC: Universidade Federal de Santa Catarina https://orcid.org/0000-0001-7911-3662

Camila Cazarin

UNIVALI: Universidade do Vale do Itajai

Marcia Souza

UNIVALI: Universidade do Vale do Itajai

\section{Research Article}

Keywords: Alzheimer, Acmella ciliata, spilanthol, alkimides, streptozotocin, TRPV1

Posted Date: March 12th, 2021

DOI: https://doi.org/10.21203/rs.3.rs-282279/v1

License: (c) (i) This work is licensed under a Creative Commons Attribution 4.0 International License.

Read Full License 


\section{Abstract}

This study investigated the effect of Acmella ciliata extract on memory impairment and oxidative stress dysfunction in the brain after intracerebral (i.c.v.) administration of $0.5 \mathrm{mg} / \mathrm{kg}$ streptozotocin (STZ) twice within $48 \mathrm{~h}$ in mice. Animals received orally treatment with ethanolic extract (50-150 mg/kg), hexane fraction $(100 \mathrm{mg} / \mathrm{kg})$ galantamine $(40 \mathrm{mg} / \mathrm{kg})$ and spilanthol $(10 \mathrm{mg} / \mathrm{kg})$, an alkamide isolated from the hexane fraction for 15 days. They were subjected to memory tests, inhibitory prevention (IAT) and the new object recognition tests (NOR). Experiments were performed with the animals' brains to evaluate the activity of catalase (CAT), superoxide dismutase (SOD), reduced glutathione (GSH), glutathione peroxidase (GPX), glutathione reductase (GR) and glutathione-S-transferase (GST) enzymes and to estimate malondialdehyde (MDA) concentration. We found that the treatments prevented STZ-induced memory loss, assessed by the IAT and NOR. Biochemical analysis revealed that STZ significantly increased levels of MDA and depleted (GSH) in mice's brain. The extract decreased oxidation, as evidenced by a significant decrease in MDA and an increase in the antioxidant markers levels in mice treated with STZ. The positive effects of plant extract and fraction on STZ-induced memory deficits appear to be related to spilanthol and its activity on TRPV1 receptors, since pretreatment with capsazapine promotes the reversal of these effects. The results together demonstrate the beneficial effects of $A$. ciliata and spilanthol in preventing memory impairment, oxidative stress and dysfunction caused by STZ in mice. Therefore, there is a potential of this plant and its main compound spilanthol in the treatment of neurodegenerative disorders.

\section{Introduction}

Alzheimer's disease (AD) is a neurodegenerative disease related to aging, characterized by slow and progressive loss of neurons in different regions of the central nervous system (CNS) and consequent deficits in memory and cognition. The main cause forthis disease is still unknown, but it occurs in the brain of patients, with accumulation of beta-amyloid peptides $(A \beta)$ and hyperphosphorylation of the tau protein, which are respectively responsible for the formation of the two histopathological findings of $A D$, the senile plaques and the neurofibrillary tangles (Kozlov et al. 2017; Gao et al. 2018; Lane et al. 2018; Swarbrick et al. 2019). Actually, $A D$ is the most common type of dementia, which accounts for $60-80 \%$ of cases. In 2018, over 46 million people live with dementia in the world and this number is estimated to increase to 131.5 million by 2050.The majority of $A D$ cases are sporadic (SAD), which involves several different etiopathogenic mechanisms, including environmental, genetic and metabolic factors (Kozlov et al. 2017; Tellechea et al. 2018).

For the research of pharmacological targets for AD many animal models are used (Drummond and Wisniewski 2017). The intracerebroventricular (i.c.v.) streptozotocin (STZ) is a well-established animal model that has been widely used for investigating this pathology (Grieb 2016; Jayant et al. 2016; Drummond and Wisniewski 2017; Halawany et al. 2017; Ravelli et al. 2017; Berté et al. 2018). STZ is a glucosamine-nitrosourea compound biosynthesized by Streptomycetes achromogenes, which is commonly used in the systemic induction of diabetes due to its ability to damage the pancreatic $\beta$ cells 
and to induce insulin resistance. Furthermore, its administration also decreases cerebral glucoseuptake and produces effects related to $A D$, such as reduced cognition and increased cerebral aggregated $A \beta$ fragments, tau protein, and A $\beta$ deposits (Grieb 2016; Drummond and Wisniewski 2017).

TRPV1, formerly known as vanilloid receptor 1 (VR1), is a nonselective cation channel with high $\mathrm{Ca}^{2+}$ permeability, that is expressed in primary sensory neurons as well as in the brain. It is activated by heat (> $42^{\circ} \mathrm{C}$ ) and phytochemicals such as the alkamide capsaicin (Crouzin et al. 2010; Nomura et al. 2013; Premkumar 2014). TRPV1 has clinical relevance to neurodegenerative disorders as its activation can decrease neuroinflammation, production of cytokines (Jayant et al. 2016), cellular injury, and oxidative stress, prevents hyperphosphorylation of AD-associated tau protein (Xu et al. 2017), and also participates in cognition, ischemic damage and neuroprotection (Gupta et al. 2014).

Acmella ciliata, one of the plants popularly known as jambu in Brazil, is an herb used in typical northern Brazil cuisine and folk medicine. Jambu is famous for its sensorial effects, such as anesthetic, numbing, tingling and cooling feeling, due to the well-known phytochemical alkamide spilanthol $[(2 E, 6 E, 8 E)-N$ isobutyl-2,6,8-decatrienamide] (Spelman et al. 2011; Silveira et al. 2016). Alkamides represent a class of natural compounds that are highly active in the CNS as they produce antinociceptive (Rios et al. 2006; Gertsch et al. 2008; Déciga-Campos et al. 2010; Ong et al. 2011; Das et al. 2014), immunomodulatory (Gertsch 2008), anticholinesterases and antioxidant effects (Tu et al. 2016). Previous studies suggest that the analgesic and antinociceptive effects could be related to TRPV1 receptors modulation (Nomura et al. 2013; de la Rosa-Lugo et al. 2017).

Considering the background, the purpose of the present work was to evaluate the protective effect of $A$. ciliata extract and spilanthol in an experimental model of AD induced by STZ in mice.

\section{Methods}

\section{Plant extraction and spilanthol isolation}

A. ciliata aerial parts were collected at the garden of the Associação dos Funcionários Fiscais do Estado de Santa Catarina (AFFESC, Florianópolis, Santa Catarina, Brazil) in October, 2012. The ethanol extract, hexane fraction and spilanthol were obtained as previously described (Silveira et al. 2016). HR-MS spectrum and chromatogram can be found as supplementary material.

\section{Drugs, Reagents and doses}

The following substances were used: STZ, capsazepine (TRPA1 channel antagonist) and galantamine (commonly used drug in the treatment of AD) were purchased from Sigma-Aldrich (St. Louis, MO, USA). The reagents (ethanol and hexane) used to obtain the spilanthol were commercial grade, purchased from VETEC (RJ, BR). Ketamine (Vetbrands, FL, USA), xylazine (Agener União, SP, BR), lidocaine with epinephrine $2 \%$ (Cristália, SP, BR). All drugs were dissolved in saline [except STZ which was dissolved in 
artificial cerebrospinal fluid prepared as described by Jayant et al. (2016) and were infused at room temperature]. The dose of galantamine used in this study as positive control in memory experiments was determined from a preliminary study based on the doses used by Berté et al (2018). The other doses used were determined based on pilot experiments. Due to the low amount of the compound, capsazepine was used only acutely administered 15 minutes before the administration of spilanthol in the inhibitory avoidance experiment.

\section{Animals and Ethical statement}

Male swiss albino mice $(25-30 \mathrm{~g})$, approximately 90 days old, were used for the study. The animals were obtained from the Universidade do Vale do Itajaí (UNIVALI). They were kept at $22 \pm 2{ }^{\circ} \mathrm{C}$ with free access to food and water, under a 12:12 h natural light (sunlight) and dark cycle, except during pharmacological assays. This study followed the guidelines established by the Research Ethics Committee of UNIVALI, and the Brazilian Law on Animal Experimentation and was approved by the Research Ethics Committee of UNIVALI (CEUA/UNIVALI), protocol 11/18.

\section{Experimental groups}

Mice were randomly divided into nine groups, each containing 8 - 10 mice:

Group $1(n=10)$ regards the sham-operated animals that did not receive STZ nor oral treatment; however, received the same amount of the vehicle used to solubilize STZ (artificial liquor), $2 \mu$ li.c.v. This group is important to show that i.c.v. does not cause hippocampal lesion interfering with behavioral and biochemical assays.

Group $2(n=9)$ is the negative control, injected with STZ ( $2 \mu \mathrm{L}$ of $2.5 \mathrm{mg} / \mathrm{ml}$; i.c.v.) and treated with a vehicle per os (p.o.) route in which extract and spilanthol were solubilized (DMSO $2 \%$ and distillated water).

Group $3(n=10)$ represents the positive control, was injected with STZ ( $2 \mu \mathrm{L}$ of $2.5 \mathrm{mg} / \mathrm{ml}$; i.c.v.), and followed by injection of galantamine $(30 \mathrm{mg} / \mathrm{kg}$, p.o.) treatment for 15 days.

Groups 4 to $6(n=10)$ are the animals that were treated for 15 days with ethanolic extract $(50 \mathrm{mg} / \mathrm{kg}, 100$ $\mathrm{mg} / \mathrm{kg}$ e $150 \mathrm{mg} / \mathrm{kg}$, p.o., respectively), dissolved in DMSO $2 \%$ and distillated water.

Group $7(n=10)$ received the hexane fraction of $A$. ciliata $(100 \mathrm{mg} / \mathrm{mL} ; \mathrm{p} .0)$.

Group $8(\mathrm{n}=10)$ was treated with spilanthol $(10 \mathrm{mg} / \mathrm{mL}$; p.o).

Group $9(n=10)$ was treated with spilanthol $(10 \mathrm{mg} / \mathrm{mL}$; p.o). and capsazepine $(40 \mathrm{mg} / \mathrm{kg})$.

Neurobehavioral tests were carried out within $24 \mathrm{~h}$ after the $15^{\text {th }}$ day of treatment (Fig. 1). 


\section{Experimental model of SAD induced by STZ}

SAD was induced by the freehand i.c.v. procedure previously reported (Pinton et al. 2010) with slightly modifications. Briefly, mice were anesthetized with xylazine/ketamine, than they were submitted to a minor surgery to remove the cutaneous tissue aiming at the exposure of the skull. After cleaning and asepsis of the cranial region, the animals still under anesthesia received STZ $(2 \mu \mathrm{L}$ of $2.5 \mathrm{mg} / \mathrm{mL}$ solution; i.c.v.) through a hypodermic needle attached to a cannula, which was linked to a $5 \mu \mathrm{L}$ Hamilton syringe. After $48 \mathrm{~h}$, each mouse received a second injection of STZ (same way as the first one). Drug treatment started after the second dose of STZ and lasted for more than 15 days, including the days of the behavioral tests. Treatment was done orally (p.o.) and experiments were carried out 1 hour after them.

\section{Behavioral tests}

\section{Novel object recognition (NOR) test}

The NOR test is used to evaluate long-term memory and also cognition. It is based on the principle that, in a familiar environment, laboratory animals show an instinctive affinity for novelty, or preference for exploring a new object rather than a familiar (Ennaceur 2010). To this end, animals from Group 1 to 6 were evaluated.

The test consisted of three different phases (habituation phase, training phase, and test phase) conducted on three successive days and followed the protocol described by Myskiw et al. (2008) with slightly modifications. Briefly, in the first phase, mice were exposed to an open field apparatus consisted of a wooden box of $40 \times 60 \times 50 \mathrm{~cm}$ dimensions and were left for $15 \mathrm{~min}$ in the absence of stimulus objects to adapt to the apparatus. On the next day animals were placed on the apparatus for $10 \mathrm{~min}$ in the presence of two identical in shape, color, and size objects put in opposite corners of the wooden box for familiarization. On day three, mice were tested by placing them again in the open field apparatus but now in the presence of a familiar and a novel object (different in shape, color and size from the other) and were left to explore the objects for $10 \mathrm{~min}$. The time taken by each mouse to explore the two objects during the acquisition and retention phases of the test were recorded manually and separately with two stop watches (by a trained observer). Its Discrimination Index (DI) wasthen calculated for the retention trial as DI=B-A1/B+A1 (B=novelobject, $A 1$ = familiar object).

\section{Effect of treatments on the locomotor activity of animals (Exploratory behavior) -Open Field Test (OFT)}

Locomotor activity was assessed using the same open field apparatus used in the NOR test. In this test, during animals' habituation phase, the exploratory behavior of them was evaluated during the first six 
minutes. Mice were placed individually in the center of the open field and crossing movements were recorded during this time.

\section{Inhibitory avoidance test (IAT)}

This experiment is used to measure long-term memory. In the present study, all nine group of animals were submitted to an IAT as previously performed (Izquierdo and Dias 1983) with some modifications. Mice were trained and tested in an apparatus consisted of a $50 \mathrm{~cm}$ long, $25 \mathrm{~cm}$ wide, $25 \mathrm{~cm}$ high plywood box with a glass frontal wall and floor made of steel bars stainless steel parallel with caliper of $0.1 \mathrm{~cm}$ and to $1 \mathrm{~cm}$ of distance of each other, with a $2.5 \mathrm{~cm}$ high, $7.0 \mathrm{~cm}$ wide, 2.5 long platform. A $15 \mathrm{~W}$ lamp lit up the apparatus, while the room remains dark. On the training trial, animals were gently placed and held on the platform facing the rear left corner. Their latency to step down (placing the four paws on the grid) was timed, and immediately after a $0.4 \mathrm{~mA}$ foot shock was delivered for $2 \mathrm{~s}$. The test session was conducted $24 \mathrm{~h}$ later. The procedure was identical to training session with omission of the foot shock. Their latency to step down was also measured up to a limit of $180 \mathrm{~s}$.

\section{Biochemical analysis}

\section{Preparation of brain homogenate}

After completion of experiments animals were killed and, whole intact brain was carefully removed and rinsed with $0.9 \% \mathrm{NaCl}$ solution for cleaning, and weighed. Braintissue was homogenized in a phosphate buffer ( $\mathrm{pH} 7.6$ ), centrifuged at $20,000 \times \mathrm{g}$, at $4^{\circ} \mathrm{C}$ for $10 \mathrm{~min}$. An aliquot of supernatant was collected and stored at $-20^{\circ} \mathrm{C}$ for furtherbiochemical tests. Protein concentrations were determined by the Bradford assay with Bovine serum albumin as standard $(0.05-1.00 \mathrm{mg} / \mathrm{mL})$.

\section{Assessment of brain antioxidant markers}

\section{Catalase (CAT) activity}

CAT activity was determined by the protocol of Maehly and Chance (1954) with slight modifications.CAT reaction solution consists of $625 \mu \mathrm{L}$ of $50 \mathrm{mM}$ of potassium phosphate buffer (pH 5), $100 \mu \mathrm{L}$ of $5.9 \mathrm{mM}$ $\mathrm{H}_{2} \mathrm{O}_{2}$ and $35 \mu \mathrm{L}$ enzyme extract. Changes in the absorbance of the reaction solution was noted after 1 min at $240 \mathrm{~nm}$. An absorbance change of 0.01 as units/min denotes one unit of catalase activity (Maehly and Chance 1954).

\section{Superoxide dismutase (SOD) activity}


In this experiment, Kakkar et al. (1984) method was utilized. Buffers were exploited for the assessment of SOD activity. Centrifugation of tissue homogenate was done at $1500 \times \mathrm{g}$ for $10 \mathrm{~min}$ and then at $10,000 \times \mathrm{g}$ for $15 \mathrm{~min}$. Supernatant was collected and $150 \mu \mathrm{L}$ of it was added to the aliquot containing $600 \mu \mathrm{L}$ of $0.052 \mathrm{mM}$ sodium pyrophosphate buffer $(\mathrm{pH} 7.0)$ and $186 \mathrm{mM}$ of phenazine methosulphate $(50 \mu \mathrm{L}) .100$ $\mu \mathrm{L}$ of $780 \mu \mathrm{M}$ NADH was added to initiate enzymatic reaction. After 1 min, glacial acetic acid (500 $\mu \mathrm{L})$ was added to stop the reaction. At $560 \mathrm{~nm}$ optical density was determined to enumerate the color intensity. Results were evaluated in units/mg protein.

\section{Glutathione-S-transferase (GST) assay}

Scheme of Habig et al. (1974) protocol was strictly followed for the estimation of GST potency. $150 \mu \mathrm{L}$ aliquot of tissue homogenate was added to $720 \mu \mathrm{L}$ of sodium phosphate buffer together with $100 \mu \mathrm{L}$ of reduced glutathione $(1 \mathrm{mM})$ and $12.5 \mu \mathrm{L}$ of 1-chloro-2,4-dinitrobenzene (CDNB) $1 \mathrm{mM}$. Changes in absorbance were recorded at $340 \mathrm{~nm}$ and enzymes activity was calculated as nmol CDNB conjugate formed/min/mg protein using a molar extinction coefficient of $9.6 \times 103 \mathrm{M}-1 \mathrm{~cm}-1$.

\section{Glutathione reductase (GR) assay}

GR activity in tissue samples was analyzed as described by Carlberg eand Mannervik (1975) with minor modifications. The reaction reagent $2 \mathrm{~mL}$ was made of of $1.65 \mathrm{~mL}$ phosphate buffer: $(0.1 \mathrm{M} ; \mathrm{pH} 7.6), 100$ $\mu \mathrm{L} \operatorname{EDTA}(0.5 \mathrm{mM}), 50 \mu \mathrm{L}$ oxidized glutathione $(1 \mathrm{mM}), 100 \mu \mathrm{L} \mathrm{NADPH}(0.1 \mathrm{mM})$ and $100 \mu \mathrm{L}$ of homogenate. Activity of enzyme was monitored by recording the absorbance of the vanishing of NADPH at $340 \mathrm{~nm}$ at $25^{\circ} \mathrm{C}$. Estimated of enzyme level was accomplished as nM NADPH oxidized/min/mg protein by employing molar extinction coefficient of $6.22 \times 103 / \mathrm{M} / \mathrm{cm}$.

\section{Glutathione peroxidase (GPx) assay}

GPx activity was assessed as described elsewhere (Jollow et al. 1974). Entire volume of $2 \mathrm{~mL}$ reaction solution comprised of $1 \mathrm{mM}$ EDTA $(100 \mu \mathrm{L}), 0.1 \mathrm{M}$ phosphate buffer( $1.49 \mathrm{ml} ; \mathrm{pH} 7.4), 1 \mathrm{mM}$ sodium azide $(100 \mu \mathrm{L}), 1 \mathrm{IU} / \mathrm{mLGR}(50 \mu \mathrm{L}), 1 \mathrm{mM}$ reduced glutathione $(\mathrm{GSH})(50 \mu \mathrm{L}), 0.2 \mathrm{mM} \mathrm{NADPH}(100 \mu \mathrm{L})$, $0.25 \mathrm{mM} \mathrm{H} 2 \mathrm{O} 2(10 \mu \mathrm{L})$ and tissue homogenate $(100 \mu \mathrm{L})$. The loss of NADPH was recorded at $340 \mathrm{~nm}$ at room temperature. Enzyme level was estimated as nM NADPH oxidized/min/mg protein employing 6.22 $\times$ 103/M/cm molar extinction coefficient.

\section{Reduced glutathione (GSH) assay}

For this assays, GSH activity was checked as described by Jollow et al. (1974) using Ellman's reagent (DTNB) as a substrate. The yellow color developed was read immediately at $412 \mathrm{~nm}$ and expressed as $\mu \mathrm{moL} \mathrm{GSH} / \mathrm{g}$ tissue. 


\section{Assessment of oxidative stress markers}

\section{Estimation of Malondialdehyde (MDA)}

This assay was carried out following the previous protocol (Wills 1966) with minor modifications. MDA is one of lipid peroxidation product that can be used as a marker of oxidative stress. The reaction mixture in a total volume of $1.0 \mathrm{~mL}$ contained $0.58 \mathrm{~mL}$ phosphate buffer $(0.1 \mathrm{~mol} ; \mathrm{pH} 7.4), 0.2 \mathrm{~mL}$ homogenate sample, $0.2 \mathrm{~mL}$ ascorbic acid $(100 \mathrm{mmoL})$, and $0.02 \mathrm{~mL}$ ferric chloride $(100 \mathrm{mmol})$. The reaction mixture was incubated at $37^{\circ} \mathrm{C}$ in a shaking water bath for $1 \mathrm{~h}$. The reaction was stopped by addition of $1.0 \mathrm{~mL}$ $10 \%$ trichloroacetic acid. Following addition of $1.0 \mathrm{~mL} 0.67 \%$ thiobarbituric acid, all tubes were placed in boiling water bath for $20 \mathrm{~min}$ and then shifted to ice bath before centrifuging at $2500 \times \mathrm{g}$ for $10 \mathrm{~min}$. The amount of thiobarbituric acid reactive substances (TBARS) formed in each of the samples was assessed by measuring optical density of the supernatant at $535 \mathrm{~nm}$ using a spectrophotometer against a reagent blank. The results were expressed as nmol TBARS $/ \mathrm{min} / \mathrm{mg}$ tissue at $37^{\circ} \mathrm{C}$ using a molar extinction coefficient of $1.56 \times 105 \mathrm{M}-1 \mathrm{~cm}-1$.

\section{Statistical analysis}

The results were submitted to one-way analysis of variance (ANOVA), followed by multiplepost hoc comparison test using the software GraphPad InStat ${ }^{\circledR}$. The results are expressed as mean \pm standard error values of the mean and $p$ lower than $0.05(p<0.05)$ were considered statistically significant.

\section{Results}

\section{Effect of treatments on the locomotor activity of animals}

Statistical analysis of the data obtained in the OFT revealed no statistical difference between the groups treated in the behavioral parameters recorded in this experiment. Our data show that the administration of treatments does not change the number of animal passages, indicating that it probably does not change the mobility of these animals in the memory tests (Results not shown).

\section{Effect of STZ and $A$. ciliata extract on exploring the old and new object discrimination index}

The NOR test was performed 16 days after STZ-induced AD. As can be seen by the statistical analysis, the discrimination index of objects for Group 2 (negative control) is significantly lower than of mice treated with the positive control galantamine (Group 3) and $100 \mathrm{mg} / \mathrm{kg}$ of $A$. ciliate extract (Group 5) ( $p<$ 0.05 ) and greater than sham-operated animals (Group 1) and treated with 50 and $150 \mathrm{mg} / \mathrm{kg}$ of $A$. ciliata 
extract (groups 4 and 6, respectively) $(p<0.01)$ (Fig. 2). These results indicate that treatment with $A$. ciliata extract increased discrimination index compared with negative group.

\section{Inhibitory avoidance test}

This assay investigated if mice developed accurate memory after they received footshock in inhibitory avoidance training trial. Therefore, mice were trained on the one-trial inhibitory avoidance task. As shown in Fig. 3B and 4B, retention latencies of mice were significantly longer in the test session compared to training trial, except for animals from Group 2 (negative group). Beneficial effects of treatments on cognitive deficits induced by STZ are best seen in panels C of Fig. 3 and Fig. 4 where we represent only the inhibitory avoidance test sessions. Significantly treatments with the extract, hexane fraction, spilanthol and galantamine produced an increase in memory of the inhibitory avoidance when compared with the vehicle group. Thus, these findings indicate that treatment of mice with $A$. ciliata extract (groups 4 to 6), hexane fraction (group 7) and spilanthol (group 8) increased accurate memory similar to treatment with galantamine. It was also demonstrated in this experiment that the pretreatment of the animals with capsazepine, an TRPV1 receptor antagonist blocked the nootropic effects of spilanthol when compared to the group that received the vehicle (Fig. 4 C).

\section{Effect of $\boldsymbol{A}$. ciliata extract on brain oxidative status of mice}

The i.c.v. application of STZ significantly decreased the activity of antioxidant enzymes in the brain tissue of mice (control). On the other hand, in animals that received STZ, the treatment with ethanolic extract $(100 \mathrm{mg} / \mathrm{kg})$ significantly improved $(p<0.0001 ; p<0.001, p<0.05)$ the activity of CAT, SOD, GSH, GR, GST, and GPx enzymes in brain tissue (Fig. 5). In addition, animals' treatment with plant's ethanolic extract was able to establish the activity of antioxidant enzymes to patterns similar to the SHAM animals which did not receive treatment with STZ and did not have cognitive deficits. Our results also demonstrate that STZ significantly increased oxidative stress markers, such as lipid peroxidation (TBARS content) (Fig. 6).

\section{Discussion}

Currently, AD represents one of the main health problems among other disorders of the CNS worldwide. Because it is a neurodegenerative pathological process in which the etiology is not fully established and the treatment is palliative, execution of adequate animal models is essential forunderstanding of its neurobiological bases and facilitates the approaches for the discovery of new therapeutic targets.

The i.c.v. STZ ratmodel is an appropriate animal model used for study of SAD type dementia (Grieb 2016; Jayant et al. 2016; Drummond and Wisniewski 2017; Halawany et al. 2017; Ravelli et al. 2017; Berté et al. 
2018). Firstly, the model was developed for rats, but it was also standardized for mice (Ravelli et al. 2017). Glucose, its metabolites and energy products metabolism (like ATP) are brain's main energy source and, therefore, normal glucose metabolism is fundamental for correct brain functions such as protein synthesis and cellular functions and molecular processes (Dienel 2019). It has been widely reported in the literature that the i.c.v. STZ model of memory deficit shows an impaired glucose metabolism. In addition, various pathological aspects of AD like impaired brain glucose and energy metabolism are closely mimicked in animals after sub diabetogenic i.c.v. injection of STZ (Mayer et al. 1990; Lannert and Hoyer 1998), which leads to progressive deficits in learning and memory in rats and mice (Grieb 2016; Jayant et al. 2016; Drummond and Wisniewski 2017; Halawany et al. 2017; Ravelli et al. 2017; Berté et al. 2018). It has also been reported in this model thatthe decrease in the levels of choline acetyltransferase in the hippocampus, leading to a decrease in acetylcholine (Costa et al. 2016), and that the septo-hippocampus system is also damaged which is drastic, since such brain structures are essential in the process of memory consolidation (Thomas 2015).

In the present work, $A$. ciliata extract was studied and itreversed deficit of memory and oxidative stress in STZ (i.c.v.) induced model of dementia. In this AD animal model, as expected, STZ caused a persistent memory deficit, as evidenced by the non-alteration in the behavior of animals in the inhibitory avoidance comparing the training and test sessions, as well as by the decrease in the index of recognition in the object recognition test. This memory deficit was reversed by treating the animals with different doses of the plant extract.

Oxidative stress might be the underlying cause related to the pathophysiology of $A D$ or associated behavioral changes. In the present study, administration i.c.v. of STZ produced oxidative stress as evidenced by the significant increase in the level of TBARs and decrease in the GSH level, associated with decreased enzymes such as CAT, SOD, GST, GR and GPX. This increase in oxidative stress may be due to an increase in the level of glucose in the brain after STZ infusion. In a beautiful experiment, Pathan and colleagues demonstrated that brain slices from rats that received an STZ infusion showed reduced glucose consumption in the incubation medium compared to control mice with a hyperglycemic condition in the brain (Pathan et al. 2006). In addition, it has also been reported that oxidative stress, due to a hyperglycemic condition (Taïlé et al. 2020) or direct effect of STZ, can cause endothelial dysfunction. So, in this model, impaired glucose metabolism and oxidative stress may be responsible for an endothelial dysfunction in animals' brains. Impaired endothelial function is accompanied by decreased cerebral perfusion that has recently been associated with dementia (Wolters et al. 2017). Our results clearly demonstrated that treatment of animals with the extract of $A$. ciliata decreased oxidative stress and, consequently, the cognitive deficit caused by the i.c.v infusion of STZ.

Phytochemically, from the hexane fraction of A.ciliata ethanol extract 10 alkamides were identified: spilanthol, (2E,7Z)-6,9-endoperoxy-N-isobutyl-2,7-decadienamide, (2E-4E-6Z-8E)-N-isobuty-12,4,6,8dodecatetraenamide, (2E-6Z-8E)-N-2-methylbutyl-2,6,8-decatrienamide,2,3-epoxy- $N$-phenylethylamide-6,8nonodiinamide, (2Z)- $N$-phenylethyl-6,8-nonadiyinamide, (2E-4E)-N-isobutyl-2,4-undecadien-8,10-diinamide, (2E)-N-isobutyl-2-undeca-8,10-diinamide, (2E,7Z)-N-isobutyl-2,7-tridecadien-10,12-diaminamide and (7Z)- 
$N$-isobutyl-7-trideca-10,12-diinamide. In our studies, both hexane fraction and isolated spilanthol were administered to animals with STZ-induced AD and evaluated in the inhibitory avoidance test. Our results showed that both treatments reduced animals' cognitive deficits by improving the memory of inhibitory avoidance.

As already reported, alkamides represent a class of natural compounds that are highly active in the CNS as they produce antinociceptive (Rios et al. 2006; Gertsch et al. 2008; Déciga-Campos et al. 2010; Ong et al. 2011; Das et al. 2014), immunomodulatory (Gertsch 2008), anticholinesterases and antioxidant effects (Tu et al. 2016). Previous studies suggest that these effects may be related to TRPV1 receptors modulation (Nomura et al. 2013; de la Rosa-Lugo et al. 2017). TRPV1 has clinical relevance to neurodegenerative disorders as its activation can decrease neuroinflammation, diminish the production of cytokines (Jayant et al. 2016), cellular injury, and oxidative stress, prevents hyperphosphorylation of AD-associated tau protein (Xu et al. 2017), and also participates in cognition, ischemic damage and neuroprotection (Gupta et al. 2014).

The relationship between alkamides and TRPV1 receptors, and among them and AD made us think that the mechanism of action of the nootropic property found in the extract and hexane fraction of $A$. ciliata, as well as spilanthol could also be related to the activation of receptors TRPV1. So, we decided to check if the pretreatment of animals with the TRPV1 receptor antagonist, capsazapine, could reverse the effect of spilanthol in animals tested in the inhibitory avoidance. Our results showed that the nootropic effect of spilanthol may be related to the TRPV1 receptors since the beneficial effect of this alkamide on the animals' memory is not observed with the pretreatment of the animals with capsazepine. Our results corroborate other results in the literature (Jayant et al. 2016; Xu et al. 2017) and point out that positive pharmacological modulation of TRPV1 channels may be a potential research target for mitigating AD. Also indirectly, it can be verified that the reduction of oxidative stress in animals with STZ infusion and treated with the plant extract as observed in this study, can be related to the presence of the alkamides present in the plant which would be modulating the TRPV1 receptors, however more experiments would be necessary to ascertain such a hypothesis.

In STZ induced memory deficit, there is a decreased activity of glycolytic enzymes resulting in a reduction in acetylcholine level (Sorial and Sayed 2017) which is intricately associated with cognition (Záborszky et al. 2018). Acetylcholine is degraded by AChE whose inhibition by AChE inhibitors is the most effective pharmacological approach for the symptomatic treatment of AD (Sorial and Sayed 2017; Weller 2018; Záborszky et al. 2018; Zhang et al. 2019). In the current study, the effect of treatments on AChE activity was not evaluated but we do not rule out the possibility that spilanthol, the compound we consider responsible for the plant's nootropic effects, has AChE inhibiting activity since it is reported that alkamides have such a property (Tu et al. 2016).

In $A D$ the most important diagnostic symptom is the loss of memory and throughout the course of the disease, various types of memories are lost by the patient including declarative and procedural (Tu et al. 2016; Drummond and Wisniewski 2017; Kozlov et al. 2017; Lane et al. 2018). As previously reported, STZ 
in addition to the biochemical changes produced in the brain of animals, induces important cognitive deficits such as the loss of different types of memory (Halawany et al. 2017; Ravelli et al. 2017; Berté et al. 2018). In the present study, to assess the effects of treatments on cognitive deficits induced by SZT, we used two memory tests that are well-known in the literature and widely used in the screening of substances with anti-AD potential (Crystal 2016): the inhibitory avoidance test and the object recognition test. The object recognition task is a behavioral test used to access declarative memory in rodents, which is based on animal's natural tendency to explore more the new object in detriment of the familiar, in a known context (Myskiw et al. 2008; Ennaceur 2010). In inhibitory avoidance, the type of memory evaluated is emotional memory. In this test, the animal learns to associate the context of the apparatus in which it finds itself, initially not aversive to receiving an electric shock in its paws (aversive) when it descends from a platform to explore the environment. Shocks occur in the training session. In the test session animals are replaced in the apparatus (on the platform) and the latency of descending the platform is timed. The difference between the latencies of descent between the training and test sessions are considered indices of memory (Izquierdo and Dias 1983). Our results showed in both memory tests the deleterious effects of STZ as already reported in the literature (Lannert and Hoyer 1998; Ennaceur 2010; Pinton et al. 2010; Costa et al. 2016; Berté et al. 2018) as well as showing that treatment with the extract, the hexane fraction and the spilanthol which were obtained from the aerial parts of $A$. ciliata can significantly mitigate such effects, pointing out the pharmacological potential of the plant in AD.

\section{Conclusion}

In conclusion, $A$. ciliata demonstrated a promising therapeutic effect in the treatment of STZ-induced Alzheimer's. The plant's effect appears to be mediated by one of its phytochemicals, spilanthol. Our results together also allow us to conclude that the therapeutic effects of the plant involve inhibition of oxidative stress, which is involved in the pathogenesis of Alzheimer's and also activate TRPV1 type receptors.

\section{Declarations}

\section{Ethical approval}

This study followed the guidelines established by the Research Ethics Committee of UNIVALI, and the Brazilian Law on Animal Experimentation and was approved by the Research Ethics Committee of UNIVALI (CEUA/UNIVALI), protocol 11/18.

\section{Consent to participate}

Not applicable.

\section{Consent to publish}




\section{Authors contributions}

AEG, LO and MGL: Pharmacological investigations. NS: Conceptualization, Phytochemical investigations and Writing. MWB, CAZ and MMS: Supervision; Methodology; Original draft; Review and Editing. All authors read and approved the manuscript and all data were generated in-house and that no paper mill was used.

\section{Funding}

Some of the pharmacological results of this work are part of the doctoral thesis of AEG and the conclusion work of Biomedical students LO and MGL. This work was financed by donations from the University of Vale do Itajaí (UNIVALI), CNPq, CAPES and FAPESC (BRAZIL).

\section{Competing Interest}

The authors declare that they have no conflict of interests.

\section{Availability of data and materials}

Original source data is provided as supplementary material.

\section{References}

1. Berté TE, Dalmagro AP, Zimath PL, Gonçalves AE, Meyre-Silva C, Bürger C, Weber CJ, Dos Santos DA, Cechinel-Filho V, de Souza MM (2018) Taraxerol as a possible therapeutic agent on memory impairments and Alzheimer's disease: Effects against scopolamine and streptozotocin-induced cognitive dysfunctions. Steroids 132:5-11. https:// doi.org/10.1016/j.steroids.2018.01.002

2. Carlberg I, Mannervik B (1975) Purification and characterization of the flavoenzyme glutathione reductase from rat liver. J Biol Chem 250(14):5475-5480.

3. Costa M, Bernardi J, Fiuza T, Costa L, Brandão R, Pereira ME (2016) N-acetylcysteine protects memory decline induced by streptozotocin in mice. Chem Biol Interact 253:10-17. https://doi.org/10.1016/j.cbi.2016.04.026

4. Crouzin N, de Jesus Ferreira MC, Cohen-Solal C, Barbanel G, Guiramand J, Vignes M (2010) Neuroprotection induced by vitamin E against oxidative stress in hippocampal neurons: Involvement of TRPV1 channels. Mol Nutr Food Res 54(4):496-505. https://doi.org/10.1002/mnfr.200900188 
5. Crystal JD (2016) Animal models of source memory. J Exp Anal Behav 105(1):56-67. https://doi.org/10.1002/jeab.173

6. Das BK, Ahmed K, Uddin A, Bhattacharjee B, Al-Amin MM (2014) Antinociceptive activity of methanol extract of Spilanthes paniculata Linn. Turk J Pharm Sci 11(2):137-144

7. Déciga-Campos M, Rios MY, Aguilar-Guadarrama AB (2010) Antinociceptive Effect of Heliopsis longipes Extract and Affinin in Mice. Planta Med 76(7):665-670. https://doi.org/10.1055/s-00291240658

8. de la Rosa-Lugo V, Acevedo-Quiroz M, Déciga-Campos M, Rios MY (2017) Antinociceptive effect of natural and synthetic alkamides involves TRPV1 receptors. J Pharm Pharmacol 69(7):884-895. https://doi.org/10.1111/jphp.12721

9. Dienel GA (2019) Brain glucose metabolism: Integration of energetics with function. Physiol Rev 99(1):949-1045. https://doi.org/10.1152/physrev.00062.2017

10. Drummond E, Wisniewski T (2017) Alzheimer's disease: experimental models and reality. Acta Neuropathol 2:155-175. https://doi.org/10.1007/s00401-016-1662-x

11. Ennaceur A (2010) One-trial object recognition in rats and mice: Methodological and theoretical issues. Behav Brain Res 215(2):244-254. https://doi.org/10.1016/j.bbr.2009.12.036

12. Gao HM, Gao Y, Tu D, Liu Y, Zhou H, Hong J-S (2018) Inflammation-Mediated Neurodegeneration: Models, Mechanisms, and Therapeutic Interventions for Neurodegenerative Diseases. In: Cavaillon JM, Singer M (eds.) Inflammation: From Molecular and Cellular Mechanisms to the Clinic,Wiley-VCH Verlag GmbH \& Co. KGaA, pp. 1255-1278

13. Gertsch J (2008) Immunomodulatory Lipids in Plants: Plant Fatty Acid Amides and the Human Endocannabinoid System. Planta Med 74(6):638-650. https://doi.org/10.1055/s-2008-1034302

14. Gertsch J, Raduner S, Tytgat J, Peigneur S, Quednow BB, Bilkei-Gorzo A, Zimmer A, Altmann KH (2008) Analgesic and neuropsychological effects of Echinacea N-alkylamides. Planta Med 74(09):1014-1014. https://doi.org/10.1055/s-0028-1084300

15. Grieb P (2016) Intracerebroventricular Streptozotocin Injections as a Model of Alzheimer's Disease: in Search of a Relevant Mechanism. Mol Neurobiol 53(3):1741-1752. https://doi.org/10.1007/s12035015-9132-3

16. Gupta S, Sharma B, Singh P, Sharma BM (2014) Modulation of Transient Receptor Potential Vanilloid Subtype 1 (TRPV1) and Norepinephrine Transporters (NET) Protect Against Oxidative Stress, Cellular Injury, and Vascular Dementia. Curr Neurovasc Res 11(2):94-106. https://doi.org/10.2174/1567202611666140305221854

17. Habig WH, Pabst MJ, Jakoby WB (1974) Glutathione S-transferases the first enzymatic step in mercapturic acid formation. J Biol Chem 249(22):7130-7139.

18. Halawany AME, Sayed NSEL, Abdallah HM, Dine RSE (2017) Protective effects of gingerol on streptozotocin-induced sporadic Alzheimer's disease: emphasis on inhibition of $\beta$-amyloid, COX-2, alpha-, beta-secretases and APH1a. Sci Rep 7(1):2902. https://doi.org/10.1038/s41598-017-02961-0 
19. Iqbal S, Bhanger M, Anwar F (2005) Antioxidant properties and components of some commercially available varieties of rice bran in Pakistan. Food Chem 93(2):265-272. https://doi.org/10.1016/j.foodchem.2004.09.024

20. Izquierdo I, Dias RD (1983) The influence of adrenergic receptor antagonists on the amnestic and antiamnestic actions of adrenaline and tyramine. Psychopharmacology 80(2):181-183. https://doi.org/10.1007/BF00427966

21. Jayant S, Sharma BM, Sharma B (2016) Protective effect of transient receptor potential vanilloid subtype 1 (TRPV1) modulator, against behavioral, biochemical and structural damage in experimental models of Alzheimer's disease. Brain Res. 1642:397-408. https://doi.org/10.1016/j.brainres.2016.04.022

22. Jollow D, Mitchell J, Zampaglione N, Gillette J (1974) Bromobenzene-inducedlivernecrosis. Protective role of glutathione and evidence for 3,4-bromobenzeneoxide as the hepatotoxic metabolite. Pharmacology 11(3):151-169. https://doi.org/10.1159/000136485

23. Kakkar P, Das B, Viswanathan PN (1984) A modified spectrophotometric assay of superoxide dismutase. Indian J Biochem Biophys 21(2):130-132.

24. Kozlov S, Afonin A, Evsyukov I, Bondarenko A (2017) Alzheimer's disease: as it was in the beginning. Rev Neurosci 28(8):825-843. https://doi.org/10.1515/revneuro-2017-0006

25. Lane CA, Hardy J, Schott JM (2018) Alzheimer 's Disease. Eur J Neurol 25(1):59-70. https://doi.org/10.1111/ene.13439

26. Lannert H, Hoyer S (1998) Intracerebroventricular administration of streptozotocin

27. causes long-term diminutions in learning and memory abilities and in cerebral

28. energy metabolism in adult rats. Behav Neurosci 112(5):1199-1208. https://doi.org/10.1037//07357044.112.5.1199

29. Maehly A, Chance B (1954) The assay of catalases and peroxidases. Methods Biochem Anal 1:357424. https://doi.org/10.1002/9780470110171.ch14

30. Mayer G, Nitsch R, Hoyer S (1990) Effects of changes in peripheral and cerebral glucose

31. metabolism on locomotor activity, learning and memory in adult male rats. Brain Res 532(1-2):95100. https://doi.org/10.1016/0006-8993(90)91747-5

32. Myskiw JC, Rossato JI, Bevilaqua LRM, Medina JH, Izquierdo I, Cammarota M (2008) On the participation of mTOR in recognition memory. Neurobiol Learn Mem 89(3):338-351. https://doi.org/10.1016/j.nlm.2007.10.002

33. Nomura ECO, Rodrigues MRA, Silva CFH, Hamm LA, Nascimento AM, Souza LM, Cipriani TR, Baggio $\mathrm{CH}$, Werner MPP (2013) Antinociceptive effects of ethanolic extract from the flowers of Acmella oleracea (L.) R.K.Jansen in mice. J Ethnopharmacol 150(2):583-589. https://doi.org/10.1016/j.jep.2013.09.007

34. Ong HM, Mohamad AS, Makhtar NA, Khalid MH, Khalid S, Perimal EK, Mastuki SM, Zakaria ZA, Lajis $\mathrm{N}$, Israf DA, Sulaiman MR (2011) Antinociceptive activity of methanolic extract of Acmella uliginosa 
(Sw.) Cass. J Ethnopharmacol 133(1):227-233. https://doi.org/10.1016/j.jep.2010.09.030

35. Pathan AR, Viswanad B, Sonkusare SK, Ramarao P (2006) Chronic administration

36. of pioglitazone attenuates intracerebroventricular streptozotocin inducedmemory

37. impairment in rats. Life Sci 79(23):2209-2216. https://doi.org/10.1016/j.Ifs.2006.07.018

38. Pinton S, da Rocha JT, Zeni G, Nogueira CW (2010) Organoselenium improves memory decline in mice: Involvement of acetylcholinesterase activity. Neurosci Lett 472(1):56-60.

https://doi.org/10.1016/j.neulet.2010.01.057

39. Premkumar LS (2014) Transient Receptor Potential Channels as Targets for Phytochemicals. ACS Chemical Neurosci 5(11):1117-1130. https://doi.org/10.1021/cn500094a

40. Ravelli KG, Rosário B.d.A., Camarini R, Hernandes MS, Britto LR (2017) Intracerebroventricular Streptozotocin as a Model of Alzheimer's Disease: Neurochemical and Behavioral Characterization in Mice. Neurotox Res 31(3):327-333. https://doi.org/10.1007/s12640-016-9684-7

41. Rios MY, Guadarrama ABA, Gutiérrez MC (2006) Analgesic activity of affinin, an alkamide from Heliopsis longipes (Compositae). J Ethnopharmacol 110(2):364-367. https://doi.org/10.1016/j.jep.2006.09.041

42. Silveira N, Saar J, Santos A, Barison A, Sandjo LP, Kaiser M, Schmidt TJ, Biavatti MW (2016) A New Alkamide with an Endoperoxide Structure from Acmella ciliata (Asteraceae) and Its in Vitro Antiplasmodial Activity. Molecules 21(6):765. https://doi.org/10.3390/molecules21060765

43. Sorial ME, El Sayed NSED (2017) Protective effect of valproic acid in streptozotocin-induced sporadic Alzheimer's disease mouse model: possible involvement of the cholinergic system. Naunyn Schmiedebergs Arch Pharmacol 390(6):581-593. https://doi.org/10.1007/s00210-017-1357-4

44. Spelman K, Depoix D, McCray M, Mouray E, Grellier P (2011) The traditional medicine Spilanthes acmella, and the alkylamides spilanthol and undeca-2E-ene-8,10-diynoic Acid isobutylamide, demonstrate in vitro and in vivoantimalarial activity. Phytother Res 25(7):1098-1101. https://doi.org/10.1002/ptr.3395

45. Swarbrick S, Wragg N, Ghosh S, Stolzing A (2019) Systematic Review of miRNA as Biomarkers in Alzheimer's Disease. Mol Neurobiol 56(9):6156-6167. https://doi.org/10.1007/s12035-019-1500-y

46. Taïlé J, Arcambal A, Clerc P, Gauvin-Bialecki A, Gonthier MP (2020) Medicinal plant polyphenols attenuate oxidative stress and improve inflammatory and vasoactive Markers in cerebral endothelial cells during hyperglycemic condition. Antioxidants 9(7):573. https://doi.org/10.3390/antiox9070573

47. Tellechea P, Pujol N, Esteve-Belloch P, Echeveste B, García-Eulate MR, Arbizu J, Riverol M (2018) Earlyand late-onset Alzheimer disease: Are they the same entity? Neurologia 3(4):244-253. https://doi.org/10.1016/j.nrl.2015.08.002

48. Thomas SA (2015) Neuromodulatory signaling in hippocampus-dependent memory retrieval. Hippocampus 25(4):415-431. https://doi.org/10.1002/hipo.22394

49. Tu Y, Zhong Y, Du H, Luo W, Wen Y, Li Q, Chao Z, Li Y (2016) Anticholinesterases and antioxidant alkamides from Piper nigrum fruits. Nat Prod Res 30(17):1945-1949. 
https://doi.org/10.1080/14786419.2015.1089243

50. Weller J, Budson A (2018) Current understanding of Alzheimer's disease diagnosis and treatment. F1000Res. 7:F1000. https://doi.org/10.12688/f1000research.14506.1

51. Wills ED (1966) Mechanisms of lipid peroxide formation in animal tissues. Biochem J 99(3):667676. https://doi.org/10.1042/bj0990667

52. Wolters FJ, Zonneveld HI, Hofman A, van der Lugt A, Koudstaal PJ, Vernooij MW, Ikram MA (2017) Cerebral perfusion and the risk of dementia: apopulation-based study. Circulation 136(8):719-728. https://doi.org/10.1161/CIRCULATIONAHA.117.027448

53. Xu W, Liu J, Ma D, Yuan G, Lu Y, Yang Y (2017) Capsaicin reduces Alzheimer-associated tau changes in the hippocampus of type 2 diabetes rats. PLoS One 12(2):e0172477. https://doi.org/10.1371/journal.pone.0172477

54. Záborszky L, Gombkoto P, Varsanyi P, Gielow MR, Poe G, Role LW, Ananth M, Rajebhosale P, Talmage DA, Hasselmo ME, Dannenberg H, Minces VH, Chiba AA (2018) Specific basal forebrain-cortical cholinergic circuits coordinate cognitive operations. J Neurosci 38(44):9446-9458. https://doi.org/10.1523/JNEUROSCl.1676-18.2018

55. Zhang P, Xu S, Zhu Z, Xu J (2019) Multi-target design strategies for the improved treatment of Alzheimer's disease. Eur J Med Chem 176:228-247. https://doi.org/10.1016/j.ejmech.2019.05.020

\section{Figures}

\section{(Behavioural tests)}

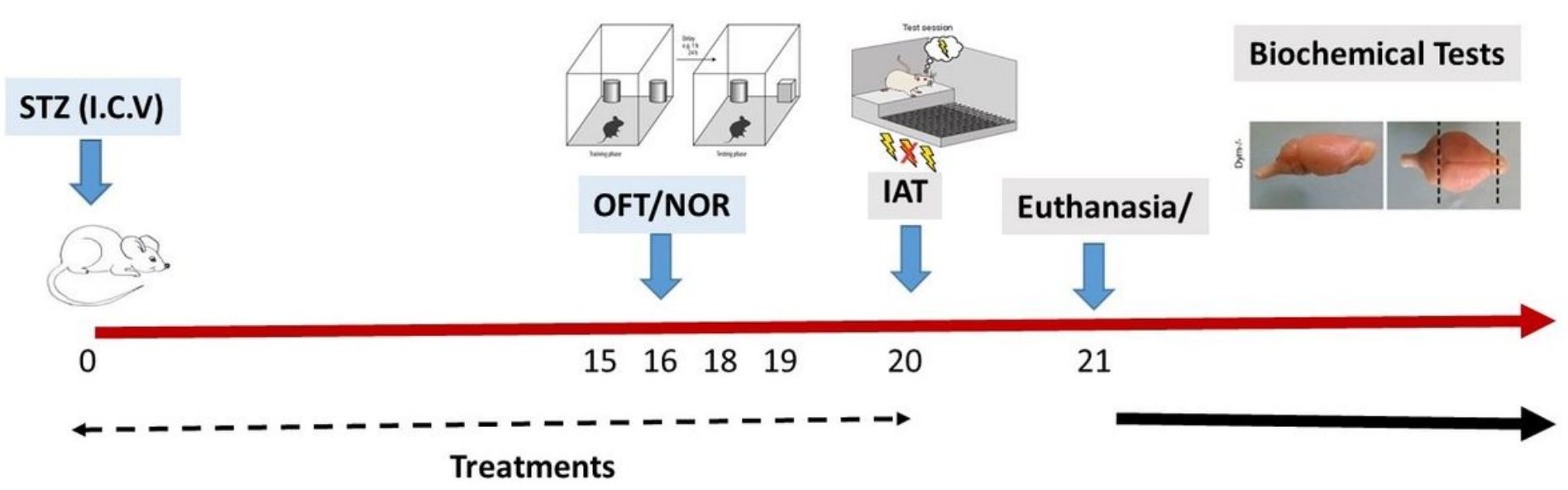

\section{Figure 1}

Timeline (in days) of experiments. OFT- Open field test, NOR- Novel object recognition test, IAT- Inhibitory avoidance test. 

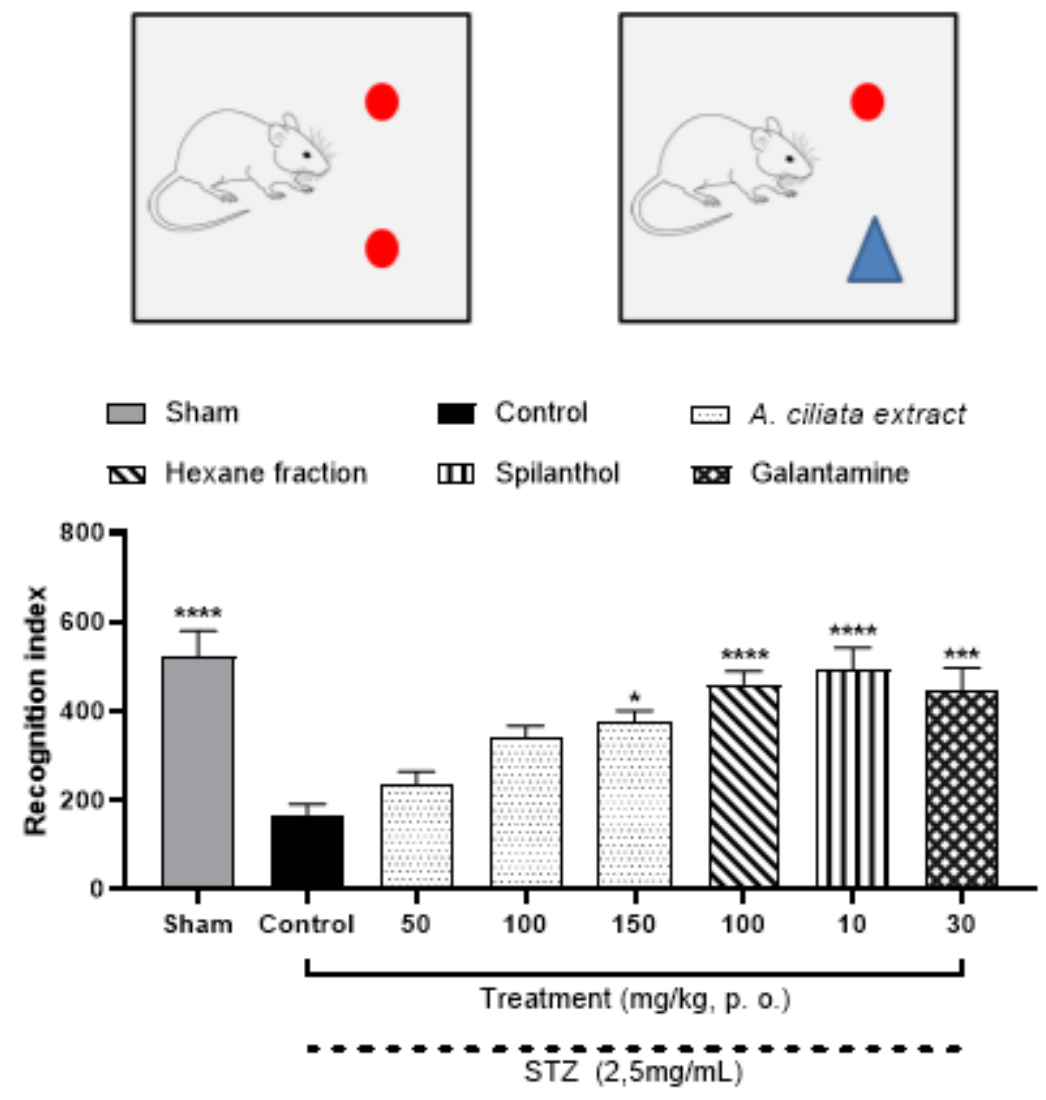

Figure 2

Effect of the treatment with A. ciliata extract $(50-150 \mathrm{mg} / \mathrm{kg}$, p.o.) and galantamine ( $30 \mathrm{mg} / \mathrm{kg}$, p.o.) on animals with STZ-induced AD and submitted to the novel object recognition test (NOR). Memory performance of mice was evaluated using the NOR. The observation time ratio (recognition index) was determined for each mouse by dividing the time exploring the new object by the total exploration time. Values are expressed as means \pm S.E.M. Statistical analysis: one-sample Student's t-test statistical analysis was performed with a threshold of $50 \%$ which corresponds to a random observation of both objects $(* p<0.05, * * p<0.01)$. Sham (fake-operated animals), which underwent the same procedures for i.c.v. STZ, but received artificial liquor. 

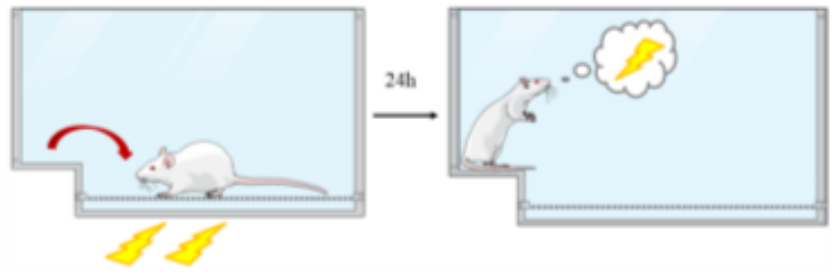
A

$\begin{array}{lll}\square \text { Sham } & \text { Control } & \text { A. ciliata extract } \\ \text { D Hexane fraction } & \text { m Spilanthol }\end{array}$

$\square$ Training session

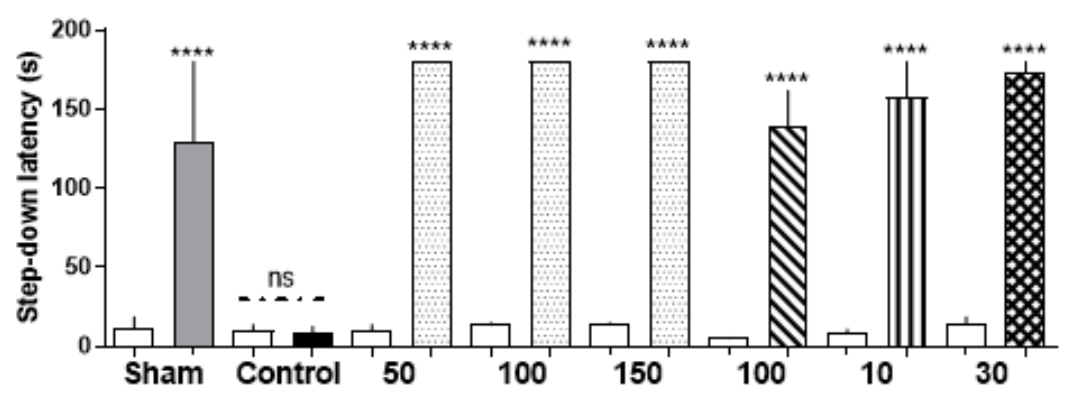

Treatment (mg/kg, p.o.)

$\mathrm{STZ}(2,5 \mathrm{mg} / \mathrm{mL}$, i.c.v $)$

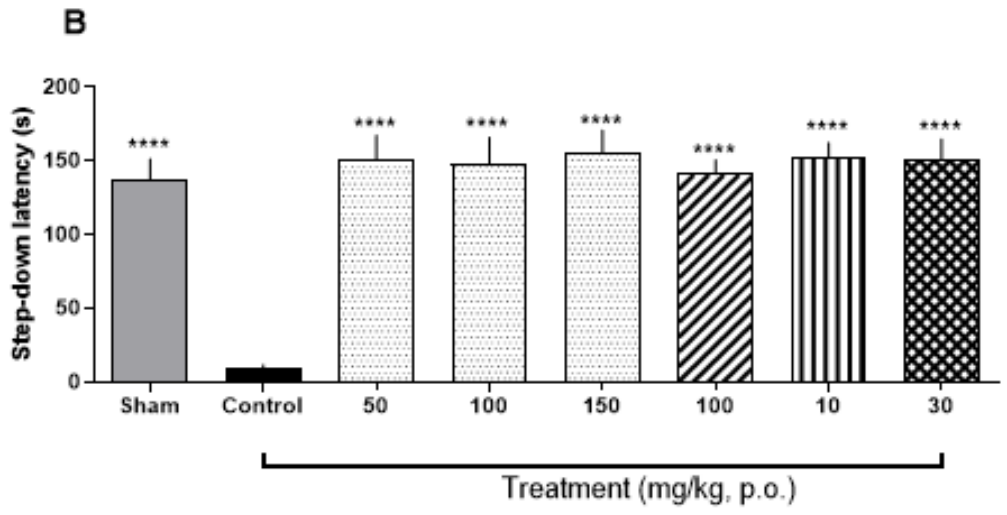

$\mathrm{STZ}(2,5 \mathrm{mg} / \mathrm{mL}$, i.c.v)

\section{Figure 3}

Effect of the treatment withA. ciliata extract (EEAC) $(50-150 \mathrm{mg} / \mathrm{kg}$, p.o) and galantamine $(30 \mathrm{mg} / \mathrm{kg}$, p.o.) on animals with STZ-induced $A D$ and submitted to inhibitory avoidance test (IAT). In plan B the results of the training and test sessions are represented and in plan $C$ the results of the test session only for better visualization of the effects of treatments. In each column, data are expressed as medians interquartile ranges from $(25 \%-75 \%)$. \# denote statistical significancewhen comparing training and testingsessions 
with the same treatment $(\# p<0.05$ and $\# \# p<0.01)$. On the other hand, asterisks $\left.{ }^{\star}{ }^{\star}\right)$ denotes statistical differencesin the test session when comparing animals receiving treatments with those who received only vehicle $\left({ }^{\star} p<0.05,{ }^{\star \star} p<0.01\right)$. ANOVA followed by the Kruskal-Wallis testbetween training and testing and the Dunnett's test between groups.Sham (fake-operated animals), which underwent the same procedures for i.c.v. STZ, but received artificial liquor.The difference between the latency of descending the inhibitory avoidance platform between the training and test sessions were considered as a memory index.

A

Training Session Test Session

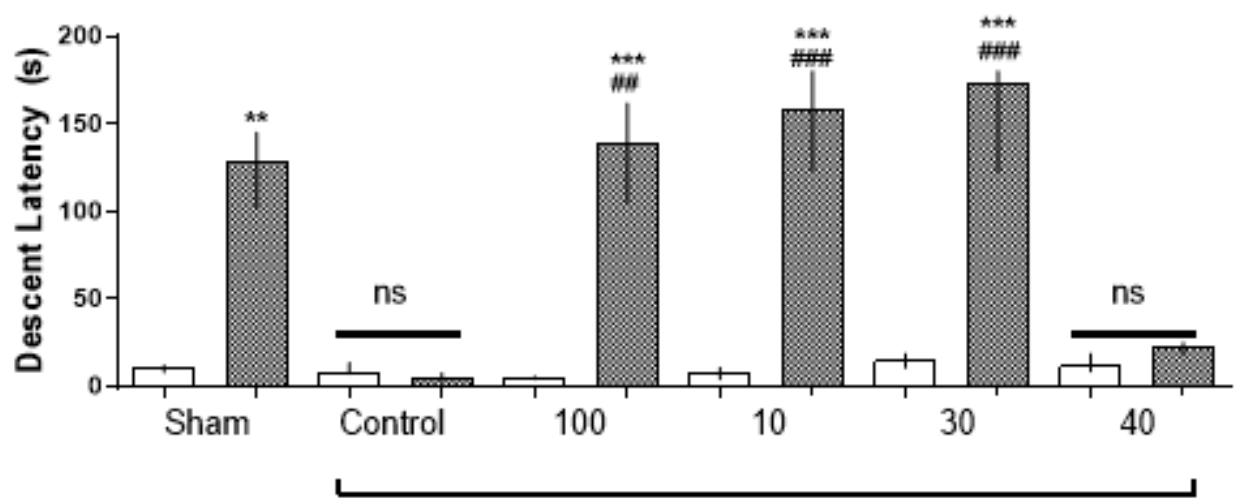

Treatment (mg/kg, p.o.)

$\ddot{s T Z} \ddot{(2,5 m g / m L})$

B

HFAC In Spilanthol Galantamine

Spilantol+Capsazepine

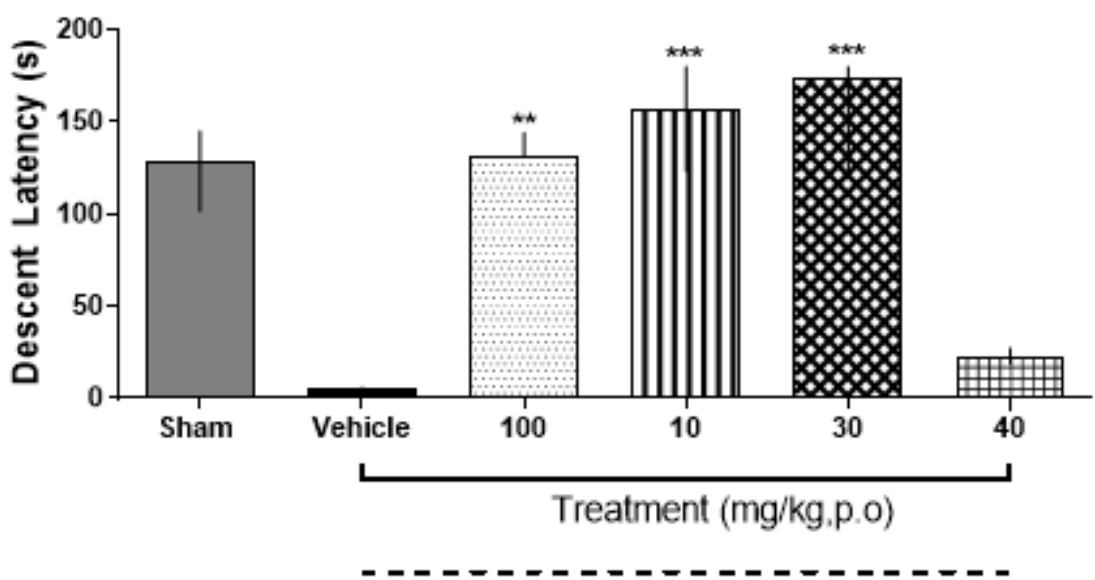

$\mathrm{STZ}(2,5 \mathrm{mg} / \mathrm{mL})$

Figure 4 
Effect of the treatment with A. ciliata hexane fraction (HFAC) $(100 \mathrm{mg} / \mathrm{kg}$, p.o.), spilanthol $(10 \mathrm{mg} / \mathrm{kg}$, p.o.) and galantamine ( $30 \mathrm{mg} / \mathrm{kg}$, p.o.) on animals with STZ-induced $A D$ and submitted to inhibitory avoidance test. In plane $B$ the results of the training and test sessions are represented and in plan $C$ the results of the test session only for better visualization of the effects of treatments. In a separate experiment a group of animals treated with spilanthol received 15 minutes before capsazepine $(40 \mathrm{mg} / \mathrm{kg}$, i.p./TRPV1 receptor antagonist). In each column, data are expressed as medians interquartile ranges from $(25 \%-75 \%)$. In B \# denote statistical significance when comparing training and testing sessions with the same treatment $\left(\# p<0.05\right.$ and \#\#p<0.01) On the other hand asterisks $\left(^{\star}\right)$ denotes statistical differences in the test session when comparing animals receiving treatments with those who received only vehicle ( $\left.{ }^{*} p<0.05,{ }^{* \star} p<0.01\right)$. In $C$ asterisks denotes statistical differences in the test session when comparing animals receiving treatments with those who received only vehicle $\left({ }^{\star} p<0.05,{ }^{\star} \mathrm{p} p<0.01\right)$. ANOVA followed by the Kruskal-Wallis test between training and testing and the Dunnett's test between groups. Sham (fake-operated animals), which underwent the same procedures for i.c.v. STZ, but received artificial liquor. The difference between the latency of descending the inhibitory avoidance platform between the training and test sessions were considered as a memory index. 

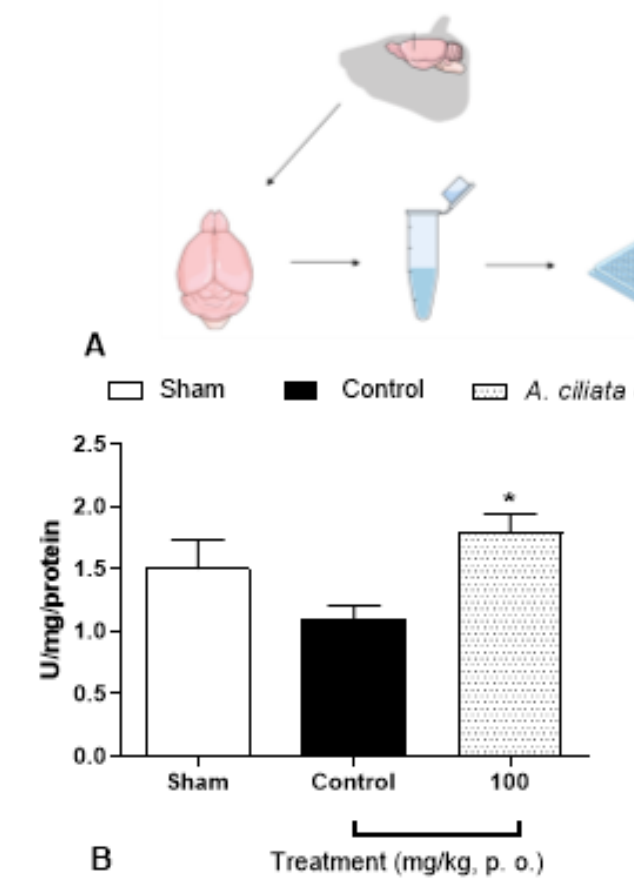

D
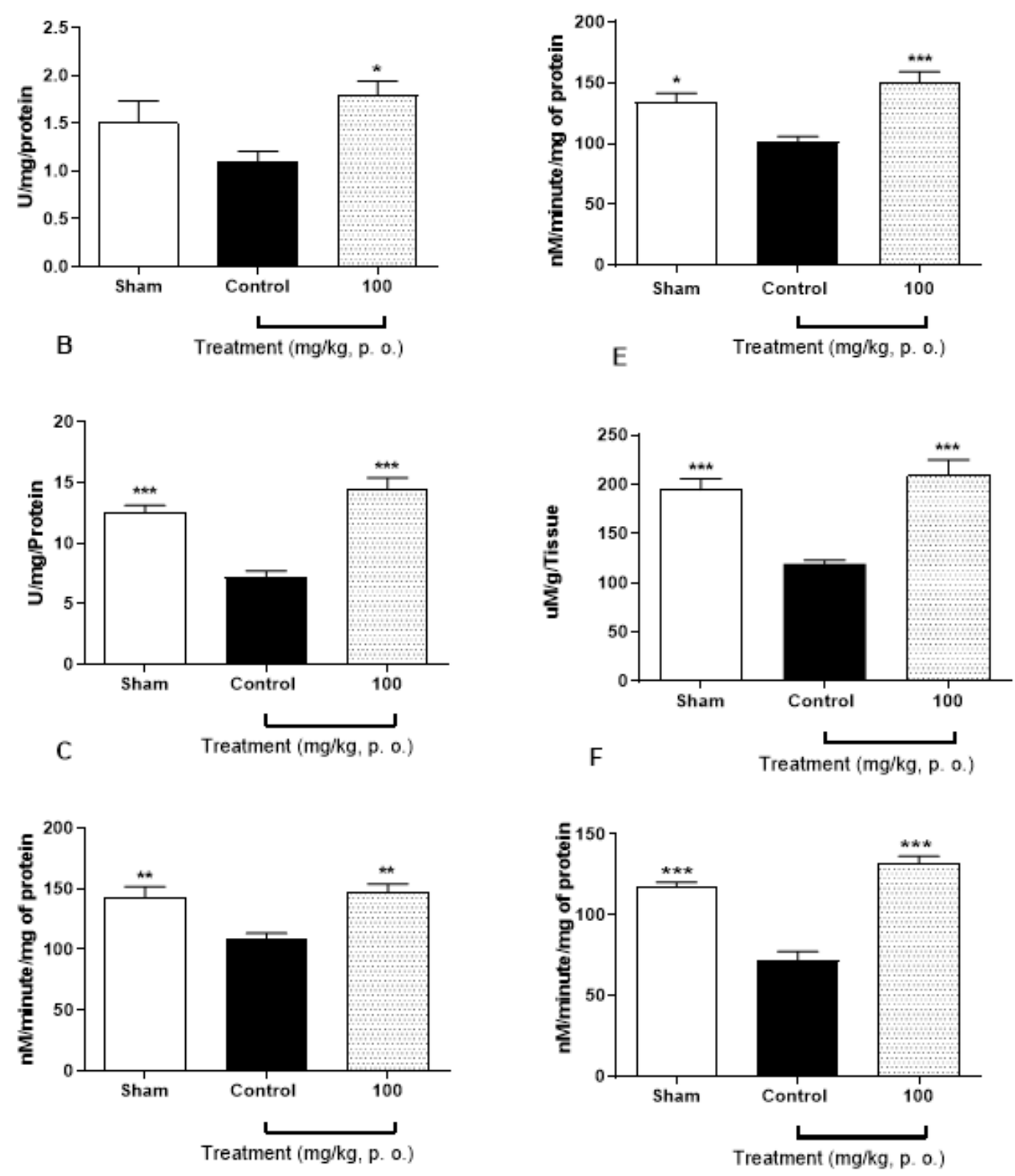

\section{Figure 5}

Effect of oral A. ciliata extract (EEAC, $100 \mathrm{mg} / \mathrm{kg}$, p.o.) on brain antioxidant status of animals with STZinduced AD. The treatment significantly increased the activity of the enzymes SOD (A), CAT (B), GR (C), GST (D), GSH (E) and GPX (F). SHAM are the fake-operated animals, which underwent the same procedures for i.c.v. STZ, but received artificial liquor. Values are expressed as mean $\pm S E M(n=10)$. **, 
$\star \star \star$ Significant difference at $p<0.001$ and $p<0.0001$ vs. control group respectively. (One way ANOVA followed by Tukey's multiple comparison tests).

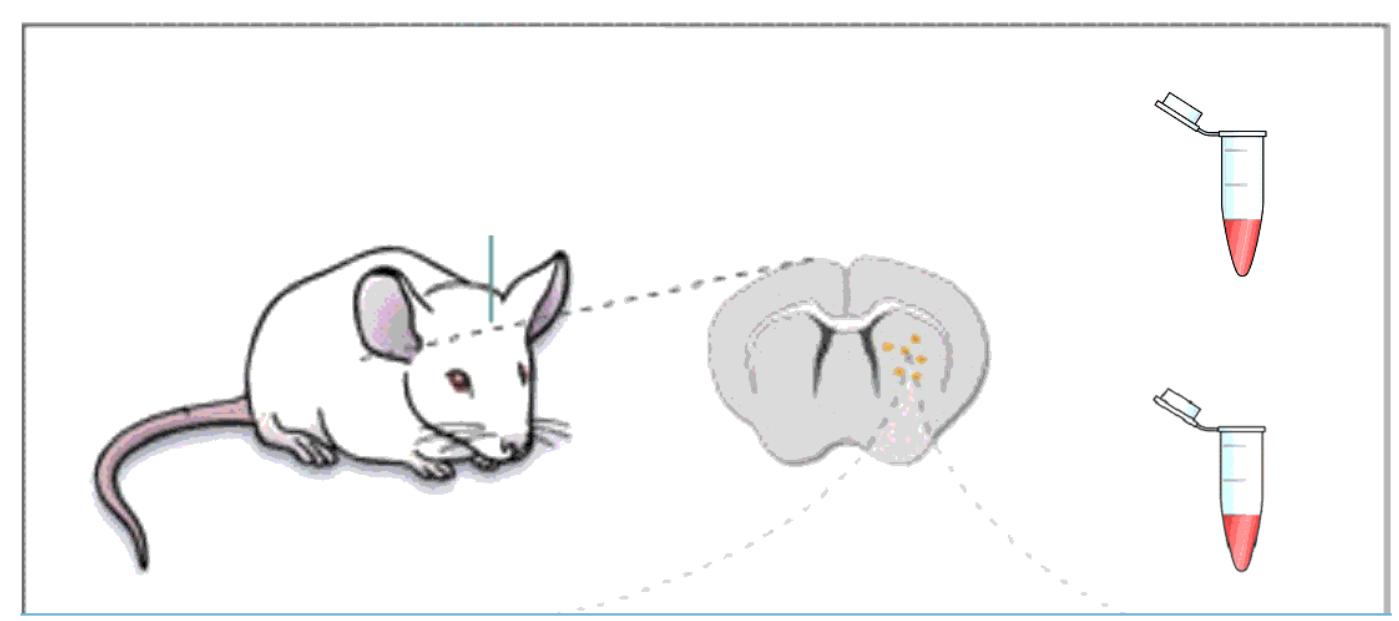

\section{TBARS}

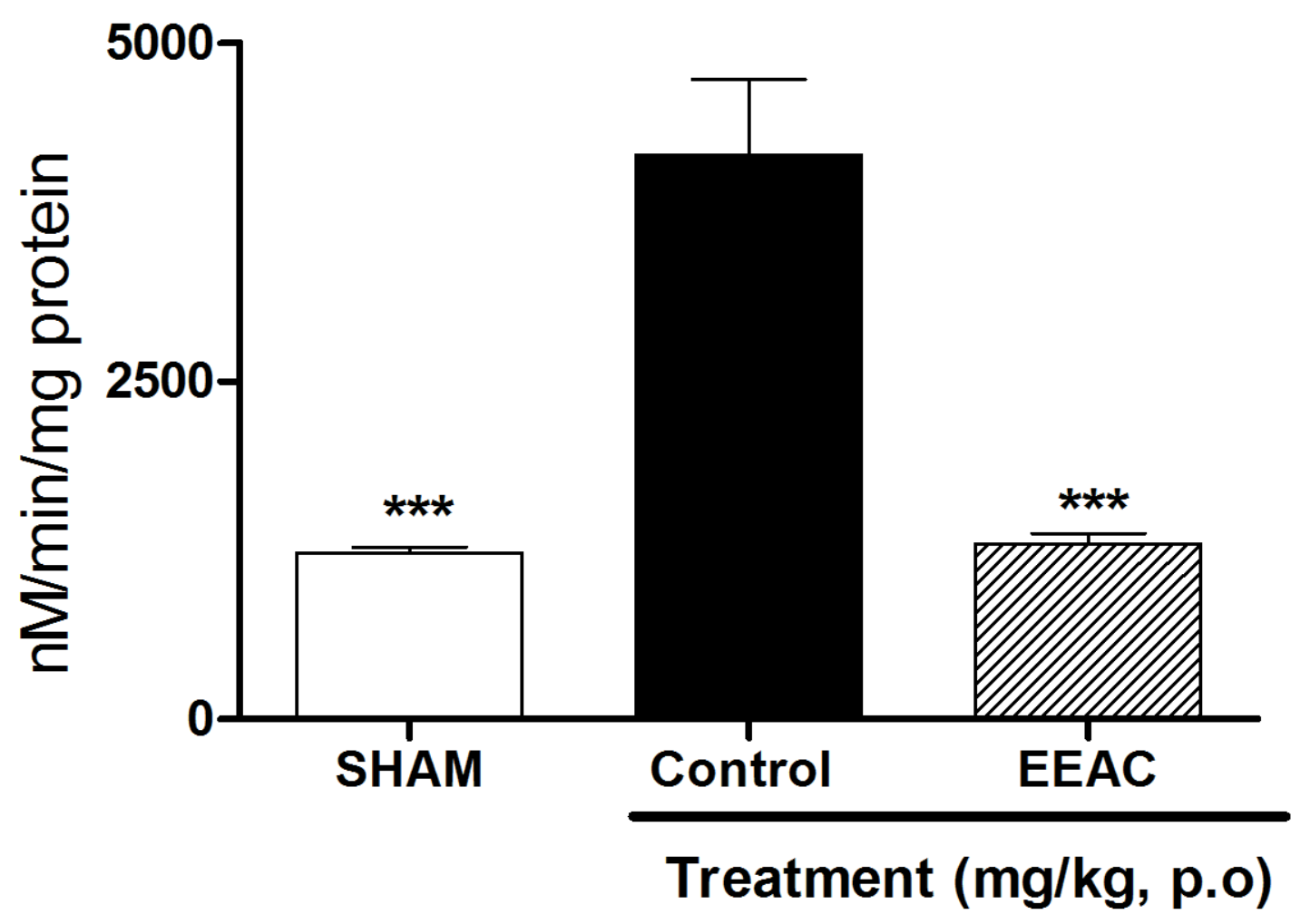

Figure 6

Effect of oral A. ciliata extract (EEAC, $100 \mathrm{mg} / \mathrm{kg}$, p.o.) on estimation of Malondialdehyde (MDA) of animals with STZ-induced AD. The results were expressed as nmol TBARS $/ \mathrm{min} / \mathrm{mg}$ tissue. The treatment significantly decreased TBARS level. SHAM are the fake-operated animals, which underwent the same 
procedures for i.c.v. STZ, but received artificial liquor. Values expressed as mean $\pm S E M(n=10)$.

***Significant difference at $p<0.0001$ vs. control group respectively (Oneway ANOVA followed byTukey's multiple comparison tests).

\section{Supplementary Files}

This is a list of supplementary files associated with this preprint. Click to download.

- ESM1.xIsx

- SUPPLEMENTARYMATERIAL.docx 